\title{
Otantiklik ve Metalaşma Kavramlarının Turizmin Sürdürülebilirliği Çerçevesinde Taraklı ve Cumalıkızık Bölgeleri Üzerinden Okunması
}

\begin{abstract}
DOI: 10.26466/opus.569837
*

Selin Aktürk $^{*}$ - Selen Durak** - Tülin Vural Arslan ${ }^{* * *}$

* Mimar, Bursa Uludağ Üniversitesi, Fen Bilimleri Enstitüsü, Mimarlık A.B.D. Bursa/Türkiye E-Posta: selinakturk93@hotmail.com ORCID: 0000-0001-7977-5965

**Doç. Dr. Bursa Uludağ Üniversitesi, Mimarlık Fakültesi, Mimarlık Bölümü, Bursa/Türkiye E-Posta: selendurak@uludag.edu.tr ORCID: 0000-0001-7499-8246

*** Prof. Dr. Bursa Uludağ Üniversitesi, Mimarlık Fakültesi, Mimarlık Bölümü, Bursa/Türkiye E-Posta: tvural@uludag.edu.tr

ORCID: 0000-0003-2072-4981

Öz

Modernleşme ile birlikte kalabalıklaşan şehirler ve bu yaşamın sunduğu tektipleşen hayatlar, kişilerin turizmden beklentisini değiştirerek özellikle kırsal alanlardaki yaşantıyı deneyimlemeyi çekici hale getirmiştir. Özgünlü̆̆̈̈nü koruyabilmiş kırsal alanların bağlı olduğu yönetimlerin ve yerel halkının bu arayıştan faydalanarak turizm amaçlı hizmete yönelmesi de bu durumun sonucunda ortaya çımıştır. Farklı deneyimler arayan turist otantik olanı keşfetmek isterken, yerel yönetimler ve halk da bu keşiften ekonomik açıdan faydalanmayı amaçlamaktadır. Bu sistem, turistin, yerel halkın ve yönetimin beklentileri üzerine kurulmuştur. Söz konusu yerlerin beklentilere cevap vererek sürdürebilirliğinin săğlanması ile koruma anlamında nispeten olumlu sonuçlar alınabilse de bu sistem planlı bir şekilde yürütülmediği takdirde bahsi geçen yerleri ticari bir araç haline getirerek yok olmaya mahkûm edecektir. Bu çalışma; kültürü, dokusu, halkı ile günümüze dek var olabilmeyi başarmış bu yerlerin, turizmin etkisiyle adeta bir pazarlama aracı haline gelmesini ve otantiklikten uzaklaşıp meta haline dönüşmesini konu edinmiştir. Alan çalışması olarak Bursa'nın 700 yıllık geçmişe sahip Cumalıkızık Köyü ve özgünlüğünü yitirmeden bugüne ulaşmış olan "Yavaş Şehir" unvanına sahip Sakarya'nın Taraklı ilçesi incelenmiştir. Güncel verilerin değgerlendirilmesinin ardından kişisel gözlemler doğrultusunda gelecekle ilgili öngörülerde bulunularak otantiklik ve metalaşma kavramlarıla yerler arasinda ilişki kurulmaya çalışılmıştır.
\end{abstract}

Anahtar Kelimeler: Otantiklik, Metalaştırma, Sürdürülebilir Turizm, Kültür Turizmi, Cumalıkızı, Taraklı 


\title{
The Concept of Authenticity and Commodification in Sustainable Tourism and Examining of Cumalıkızık and Taraklı
}

\begin{abstract}
With the increase of urbanization, almost standardized lifestyles directed people to different quests in terms of tourism and it became especially attractive to experience life in rural areas. This is the result of the fact that the administrations that have continued to exist while maintaining their originality and the local people who still live here, have taken advantage of this quest and started to serve for tourism purposes. On the one hand, tourists seeking different experiences tend to explore authentic areas, while local governments and the public aim to provide economic benefits from this discovery. This system, which is based on the expectations of the tourist, local people and the administration, can provide relatively positive results in terms of protection in order to maintain this cycle, but these places will be sentenced to be seen as a commercial vehicle unless the system is planned. In this study, it is explained that these places, which have been able to exist with their culture, texture and people until today, become a marketing tool and become a commodity. In the field study, The Cumalikızlk Village of Bursa with a history of 700 years and the Tarakl district of Sakarya, which is still able to preserve its originality and has been named as Slow City, has been investigated. Following to the current data on these places, the relationship between authenticity and commodification concepts of locations was tried to be established by making predictions about the future in accordance with personal observations.
\end{abstract}

Keywords: Authenticity, Commodification, Sustainable Tourism, Cultural Tourism, Cumalıkızk, Taraklı 


\section{Giriş}

Turizm sektörü pek çok farklı türü içinde barındırırken her biri için ekonomik, ekolojik ve sosyal yapıda meydana getirdikleri gelişme veya değişmelerden söz edilebilir. Günümüz turizm anlayışındaki değişimlerle birlikte turistin farklı deneyimler kazanma beklentisi, kültür turizmi ve kırsal alan turizmine olan rağbeti artırmıştır. Bu durumun sonucunda turizme imkân veren bu yerlerde ve toplumlarda bazı değişimler meydana gelebilmektedir.

Turistin kırsal alandan ya da kültürel turizmden beklentisi doğal olana daha yakın olabilmek, bir başka deyişle "otantiklik" deneyimini tadabilmektir. Turist, devam edegelen yerel yaşantılara belli bir zaman diliminde dahil olabilmek ve böylece özel bir deneyim yaşayabilmek arzusundadır. Diğer taraftan bakıldığında ise yerel halkın turizmden ekonomik beklentisini karşılama isteğiyle ortaya çıan otantik olanı sergileme çabası, bu yerleri bazen doğal olmaktan uzaklaştırıp ticari ürün haline dönüştürebilmektedir. Asıl olanın kötü görülen özellikleri maskelenerek iyi yönler abartılabilmekte, törenler, gelenek ve görenekler bağlamdan uzaklaşıp gösteri haline dönüşebilmektedir. Mekân açısından düşünüldügüünde ise ticari beklenti esas alınarak yapılan müdahale ve eklentilerle "metalaşan" bu yerler zamanla otantik beklentiye cevap veremeyecek birer süs unsuruna dönüşebilmektedir.

$\mathrm{Bu}$ durum kırsal alan turizmine imkân veren bu yerlerin doğallığının ve yerel halkının esas yaşantısının yitirilmesine sebebiyet verirken, aksi hedeflendiği halde turizmin de sürdürülebilirliği tehdit altına girmektedir. Nitekim sürdürülebilirlikten bahsedemediğimiz her yer veya kavram da zamanla kendisi olmaktan uzaklaşıp yok olmaya mahkûm hale gelmektedir.

\section{Kültür Turizmi}

Günümüzde turistlerin seyahatlerde artık deniz, kum, güneş üçlüsünün dışına çıkmak istemesi ve farklı deneyim arayışları turizmin çeşitlenmesine imkân vermektedir. Bu çerçevede düşünüldüğünde kültür faktörü önemli bir seyahat türünü oluşturmaktadır. 
Kültürel turizmin Dünya Turizm Örgütü tarafından yapılan tanımı; eğitim, sanat, festival ve etkinliklere katılma, anıt ve sitleri ziyaret etme, doğa veya folkloru inceleme ve dini ziyaret gibi kültürel motivasyonlarla kişilerin hareket etmesidir (Çetin, 2010). Kişilerin farklı ve otantik yerleri ziyaret etmeyi istemeleri kültürel alanlara yapılan gezilerin artmasını sağlamaktadır. Turistler gezileri süresince kültürel anlamda keşif yapma isteği içinde olduklarından, kültür turizmi giderek gelişme göstermektedir (Wang ve diğerleri, 2006). Alternatif turizm türlerinden olan kültür turizmi, değişen seyahat eğilimleri ve turistlerin beklentileriyle birlikte böylece giderek büyümektedir.

Kültürel turizm ile ilgili çalışmalarda, kültür turizmi, kültürel turizm, tarihi turizm, miras turizmi gibi kavramların kullanıldığı bilinmektedir (Çetin, 2010). Kültür turizmi bağlamında bir alt başlık da kırsal alanların turizm potansiyelinin değerlendirilmesi yönündedir. Kırsal hayatın sunduğu saf yaşantı, yörelerin çeşitli adetleri, giyim tarzları, doğal ürünlerle yapılan çeşitli yemekler, bölgelere göre değişen yapı tipolojileri turistin ilgisini çekmektedir. Yerleşimlerin koruma altına alınmış veya Yavaş Şehir ünvanı almış olması bu çekiciliği daha da artırmaktadır. Korunmaya devam eden kırsal yerleşimler ve hızlı yaşam tarzından uzaklaşıp nefes almaya imkan veren Yavaş Şehirler şehirleşmenin olumsuz etkilerinden ve tahribinden kurtulma, doğal alanlara duyulan özlem ve bu alanlarda tatil yapma, dinlenme ihtiyacının karşılanmasında ön plana çıkmaktadır. Kırsal turizm bu noktada tercih sebebi olup bununla birlikte bahsedilmesi gereken en önemli kavramlardan biri de "sürdürülebilirlik" olarak karşımıza çıkmaktadır.

\section{Sürdürülebilir Turizm}

Sürdürülebilir turizm kavramı, 1990'lı yıllarda turizm sektörünün gelişim süreci ile birlikte, artan bir biçimde tartışılmaya başlanmış ve özellikle Brundtland raporunda tanımlanan "sürdürülebilir kalkınma" kavramı ile birlikte dikkatleri üzerine toplamaya başarmıştır. Sürdürülebilir kalkınmanın, çevresel değerler üzerinde olumsuz etkiye neden olmadan, ekonomik kalkınmanın devam ettirilmesini vurguladığı göz önünde bulundurularak, Dünya Turizm Örgütü sürdürülebilir turizmi; sektörü besleyen doğal çevre ve insan kaynaklarını olumsuz yönde 
etkilemeden, turizm kapasitesinin ve ürünlerinin kalitesini artırmak olarak tanımlamaktadır (İnam, 2009). Dünya Turizm Örgütü bu tanımı yaparken sürdürülebilirliği; ekolojik, sosyal ve kültürel ve ekonomik sürdürülebilirlik olarak üç temel başlıkta incelemiş ve bu bağlamda sürdürülebilir turizm ise; kültürel bütünlügü̈, gerekli ekolojik süreçleri, biyolojik çeşitliliği ve yaşam destek sistemlerini korurken ekonomik, sosyal ve estetik gereklilikleri yerine getirmek suretiyle tüm kaynakların korunmasını ve yönetilmesini sağlayan turizm olarak tanımlanmıştır (Gürer, 2003). Böylece sürdürülebilir turizmin gelecek için yeni fırsatlar sağlıyor olmasının yanında bugün turistlerin ve ziyaret edilen bölge ile halkının ihtiyaçlarını karşılayan bir sistem oluşturduğu düşünülmektedir.

Günümüzde hemen her konuda birtakım değerlerin korunabilmesi adına gündeme gelen sürdürülebilirlik, turizmde de bölgesel, yerel ve doğal değerlerin korunabildiği ölçüde bahis konusu olabilir. Çakılcığlu (1996) sürdürülebilir turizmdeki temel yaklaşımı insanın doğal çevre üzerindeki etkisini en aza indirmek olarak değil, doğal çevrenin insan üzerindeki etkisinin en üst noktaya çıkarılması olarak tanımlar. Bir başka deyişle öncelikli amaç insanoğlunun doğal çevre üzerindeki olumsuz etkilerini en aza indirmek ve böylece korunan çevrenin de doğal olarak insanlar üzerindeki etkisinin en üst seviyeye yükselmesini sağlamaktır.

Böylece sürdürülebilir turizmde asıl önemli olan söz konusu alanların turizmin olumsuz etkilerinden korunması ve bugünden bu korumacı yaklaşımla bilinçlenerek gelecekte de çevresel sorunlardan uzak, yerin değerini yitirmeden varlığının devamlılığının sağlanmasıdır. Bu çerçevede sürdürülebilir turizm ilkelerinden bahsetmek gerekir ki Dünya Turizm Örgütü sürdürülebilir turizmin üç temel ilke etrafında bir araya geldiğini öngörmüştür. Bunlar; ekolojik ve biyolojik çeşitliliğin korunması, ev sahibi toplumların kendilerine has sosyokültürel özelliklerinin bozulmaması ve yerel halkın turizm endüstrisinde istihdam edilerek toplumsal yaşam standartlarının yükseltilmesidir (Garda ve Temizel, 2016). Bu ilkeler doğrultusunda alınan karalar ve yapılan uygulamaların sürdürülebilirliğe katkı sağlayacağı düşünülmektedir. 


\section{Otantiklik ve Metalaştırma}

Otantik sözcüğü, Türk Dil Kurumu sözlügünde batı dillerinden (Fransızca) Türkçeye geçen, Fransızcada "authentique" kelimesinin karşılığı olarak; "eskiden beri mevcut olan özelliklerini taşıyan", "gerçek olan, gerçeğe veya aslına dayanan, orijinal, mevsuk" olarak tanımlanmaktadır. Heitmann, otantikliği en basit haliyle, "öz ve saf, gerçek şey" olarak ifade ederek yapılışından beri dokunulmamış ve modernitenin etkisine maruz kalmamış olarak belirlemektedir(Kaygalak ve diğerleri, 2013). Sedmak ve Mihalic (2008) de benzer bir şekilde otantikliği, "modern turizm gelişmeden önce de mevcut olan, açıç̧a ithal edilmemiş ya da tamamen yerel olan ve kitle üretimi ya da endüstriyel amaçlarla üretilmemiş mimari, mutfak, soyut miras, doğal çevre gibi turistik çekim merkezlerinin çekicilikleri" olarak tanımlamaktadırlar.

Mimari koruma alanında ise otantiklik kavramı birçok tanımdaki "gerçeklik, sahte olmamak" anlamından farklılaşarak; tarihsel süreçle bağlantılı "doğru, samimi, orijinal" anlamında kullanılmaktadır (Ulukan, 2014). Böylece söz konusu yapının; malzemesi, işçiliği, formu, fonksiyonu ve kentin içindeki konumu, bağlamla kurduğu ilişki ile sahip olduğu tarihsel öz kimliğini anlatan geniş kapsamlı bir kavram karşımıza çıkmaktadır.

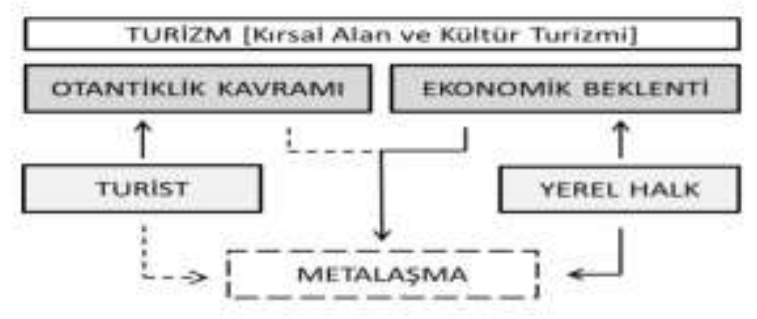

Şekil 1. Turizmin metalaşmasında roller

Otantiklik kavramı, turizm kavramıla, özellikle alternatif turizm türlerinin tercih edilmesiyle birlikte daha çok anılmaya başlanmıştır. Kültür turizminde ya da kırsal turizmde turistin saf olanı deneyimleme beklentisini karşılayabilmek adına yapılan çalışmaların söz konusu yer için hem 
kültürel hem fiziksel olumlu ve ya olumsuz yönlerinden bahsetmek mümkündür. Turizm ile birlikte yerel el sanatları, gelenekler, müzik ve dans gibi uygulamalar yeniden canlanır, korunması gerekli yapılar bu uğurda korunur.

Bu aşamada varlığın sürdürülebilmesi olumlu bir sonuç doğururken, ürünlerin, kültürel ritüellerin ve ya yapıların sadece turistler için üretiliyor ya da sözde korunuyor olması olumsuz etki olarak karımıza çımaktadır. Modern dünyanın getirdiği otantik olana açlık, seyahat tercihini bu yönde kullanmayı beraberinde getirirken otantiklik kavramı tüm bu değerleri ifade etmek için kullanılıp hatta satılmaktadır. Bu durumda her rolün farklı beklentileri oluşmakta ve sonuç metalaşma olarak karşımıza çıkmaktadır (Şekil 1).

MacCannell (1999), otantik mekânların turizm merkezleri olmasıyla birlikte yerel halkın kültürel ürünlerini turistin arzularına göre şekillendirmeye başlayacağını açıkça belirtmektedir. Sonuç olarak yerel halkın gözünde anlamsızlaşan değerler birer ticaret nesnesi olarak görülerek varlığını bu şekilde devam ettirmeye başlamaktadır. Sonuçta turistin arzuladığı otantiklik de aslında yitirilmeye başlar ve hizmetler yapay bir sunuma dönüşür. Tam da bu noktada karşımıza çıkan kavram ise "metalaşma"dır. Değerlerin zamanla ticari getiri aracı haline dönüşmesi ve yerel halkın ve ya hükümetin o yerin maddi getirisine talip olması metalaşma sonucunu doğurmaktadır.

Turizm sektörü de yerelin ve otantiğin bir "meta" olarak sunuluşunun en bariz olduğu alanlardan biri kabul edilmektedir. Çünkü turizm, modernizmin ürettiği ve pek çok alanda bizlere sunulan paketleme, pazarlama ve tükettirme anlayışının en açık biçimde görüldüğü sektörlerden biridir. Böylece, hizmet sektörü olmasına rağmen turizm bir sanayi sektörü gibi algılanarak yapısını üretim ve tüketim ilişkisi üzerine oluşturmaktadır. Bunun sonucunda ise Türk kültür ve değerlerinin yansıtıcısı ve simgesi olan kültürel değerler sözde turizm faydacılığına feda edilmektedir. Üretilen bu yapay otantiklik ve yöresellik algısı ise herkesçe özümsenmektedir (Özünel, 2011).

Turizm alanında kültürün metalaştırılması üzerine ilk çalışmaları yapan araştırmacılarından birisi Greenwood'dur. Greenwood'a (1977) göre metalaştırılan kültürel ürünler, süreç içerisinde onları yeniden üretmek için hevesini kaybeden yerel halk tarafından önemini ve gerçek anlamını 
yitirmektedir. Taylor (2001) ise kültürün turizm nesnesi olmaya başlamasıyla otantikliğin azaldığını belirtir. Kırsal bir yörenin gelişmesiyle yöre modernleşmekte ve turist toplumu halini almaktadır. Artık daha fazla ilk halinde olmadığından cazibesini kaybetmektedir (Kaygalak ve diğerleri, 2013). Sonuçta ne orada yaşanan hayatlar aslını tekrar etmekte ne de yapaylaşan ve üretim haline dönüşen yaşam turisti memnun etmektedir. Böylece sürdürüldüğü zannedilen değerler esasında yitip gitmektedir.

\section{Amaç}

Çalışmanın temel amacı, günümüzde alternatif arayışlar içerisine giren turizm sektörünün, yerel özellikleri bakımından tercih sebebi olan yerlerdeki etkisini inceleyebilmektir. Bu yerlerdeki turizmin yerel halk ve turist açısından ne ifade ettiği tartışılıp sürdürülebilir turizm ilkeleri doğrultusunda mevcut durumun değerlendirilmesinin ardından gelecekte oluşabilecek tehditlerden korunabilme konusunda öneriler geliştirebilmektir. Bu noktada hem yapılan çalışmalara güncel bir katkı sağlamak hem de otantikliği ile öne çıan turizm bölgelerinin dengeli korunumu için bir çerçeve sunabilmek amaçlanmıştır.

\section{Kapsam}

Alan çalışması olarak Bursa'nın Cumalıkızık Köyü ve Sakarya'nın Taraklı ilçesi incelenmiştir. Turizmin etkilerini farklı boyutlarda hissedebildiğimiz bu yerlerde bugüne kadar turizm anlamında ne gibi çalışmalar yapıldığı ve şuan ne durumda oldukları karşılaştırmalı olarak aktarılmıştır.

\section{Cumalıkızık}

Cumalıkızık Bursa'nın doğusunda, Uludağ'ın kuzey yamaçlarında, deniz seviyesinden 340 metre yükseklikte ve şehir merkezine $12 \mathrm{~km}$ uzaklıktadır. Oğuz boylarından Kızık'lar tarafından kurulan yedi köyden biri olan Cumalıkızık'ın kuruluşu 1300 yıllarına dayanmaktadır. Köyün yakınlarında Bizans dönemine ait kilise kalıntısının bulunması, Bizans 
Döneminde yörede yerleşimin bulunduğunu gösterir (Çetin, 2010). Köy, kurulduğundan bugüne Bursa ile karayolu bağlantısını hiç kaybetmemiş ve bu bağlantı günümüzde de devam etmektedir.

Anadolu Selçukluların zayıflama döneminde Anadolu'ya gelen Türkmen boylarından "Kızıklar", önceleri Tokat dolaylarına daha sonra Ertuğrul Gazi zamanında Bursa'ya yerleşerek, yaşamlarını burada sürmüşlerdir. Ertuğrul Gazi Kızıklara Bursa'ya yakın olan Uludağ eteklerini yurt olarak vermiştir. Köyün kuruluşuna dair çeşitli rivayetler olmasına karşın bunlardan en kabul göreni, köyün camisinde Bursa'nın fethinden sonra Cuma namazının kılınmış olmasından dolayı bu ismi aldığıdır. Orhangazi Vakfiyesi'nde köyün ismi "Camilikızık" olarak geçmekte ve bir vakıf köyü olduğu belirtilmektedir (Yılmaz, 1999).

Cumalıkızık Köyü, Marmara Bölgesinin en yüksek dağı olan Uludağ'ın (2.543 m.) eteklerinde yer alması itibariyle kışın genel olarak sert iklimin etkisi altındadır. Yazın hava sıcak olmakla birlikte akşamları sıcaklık düşmektedir (Erdemli, 2012). Köyün ana geçim kaynağ 1960'l1 yıllara kadar kestane üretimi iken günümüz itibariyle köy halkı geçimini turizm sektöründen ve bahçecilik ile pazarcılık ekonomisinden sağlamaktadır. Cumalıkızık Köyü nüfusu ise 2018 TÜİK verilerine göre 327 erkek ve 387 kadın olmak üzere 714 kişidir.

Köy organik sokak dokusuna sahiptir ve taş ile ahşabın birlikte kullanıldığı geleneksel konutlar eğime göre inşa edilmiştir. Evler, avlulu ve bahçeli olup, yüksek duvarlar iç yaşantı ile dış yaşantıyı birbirinden ayırmaktadır.

\section{Taraklı}

Taraklı, Marmara Bölgesi'nde Sakarya iline bağlı bir ilçedir. Sakarya'dan $65 \mathrm{~km}$. uzaklıktaki yerleşme, eski İstanbul-Ankara karayolu üzerinde, Göynük ve Geyve İlçeleri arasında kalmaktadır. Sakarya ilinin en önemli yaylası olan Karagöl Yaylası buradadır. En önemli akarsuyu, Göynük'ten gelip Taraklı'nın içinden geçtikten sonra Geyve'den Sakarya Nehri'ne karışan Göynük Deresi'dir (“Taraklı", 2017).

Taraklı'nın bulunduğu bölgede yerleşmenin Paleolitik döneme kadar uzandığı tahmin edilmektedir. Bizans döneminde Taraklı yakınında bulunan Göynük ile birlikte piskoposluk merkezi olduğu tahmin 
edilmektedir. Aktaş'a (2004) göre; Taraklı 1072'de Selçuklu Türkleri'nin, 1096 yılında Haçlılar'ın, 13. yy başında İznik Bizans İmparatorluğu'nun ve 1291'de Osmanlı topraklarının içerisinde kalmıştır (Kan, 2009).

İlçe 4 mahalle ve 22 köyden meydana gelmektedir. 3 mahallesi ilçe merkezinde iken(Hacı Murat, Ulu Cami, Yusuf Bey Mahalleleri) 1 mahallesi (Yenidoğan Mahallesi) ilçe merkezine 6 km uzaklıktadır. Taraklı' nın denizden yüksekliği 450 metredir. Çevresindeki dağ ve tepelerin yüksekliği 600 ile 900 metre arasındadır. Arazinin tamamına yakını engebelidir. Konutlar eğime uygun şekilde yerleşmiştir. İklim bakımından Akdeniz iklimi ile Karadeniz iklimi arasında geçiş özellikleri gösterir.

Taraklı'nın bugünkü ekonomik yapısı meyveciliğe ve küçük esnaf grubunun oluşturduğu ticarete dayanmaktadır. Meyvecilik, arazinin tarıma elverişsiz olması nedeniyle oldukça gelişmiştir. 1953 yılma kadar Taraklı çevresinin meyve bahçeleri, bağlar ve zeytinlikler, fındıklarla örtülü olduğu ve o dönemlerde Taraklı' nın elma ve eriğinin ün yaptığ 1 bilinmektedir (Kan, 2009). 2018 TÜİK verilerine göre Taraklı'nın toplam nüfusu 6.895, ilçe merkezinin nüfusu ise 3.151'dir.

Taraklı'da dar ve eğimli sokaklara yerleşmiş sivil mimari örnekleri çoğu ahşap konutlardan oluşmaktadır. Pek çoğu restore edilmiş ve asılları korunmuştur. Genel itibariyle cephede beyaz rengin hakim olduğu görülür. Sokaklar Arnavut kaldırımlıdır.

\section{Yöntem}

Konuyla ilgili çalışma literatür taramasının ardından alanlarda yapılan analizlerden elde edilen bilgilerin yorumlanması ile oluşturulmuştur. $\mathrm{Bu}$ esnada mevcut durumun belgelenmesi adına çalışma fotoğraf ve haritalama yöntemi ile desteklenmiştir. Daha kesin bilgiler alabilmek adına çalışma alanlarının bağlı olduğu belediyelerle de görüşmeler yapılmıştır.

\section{Bulgular}

Alanlar sürdürülebilir turizmde otantiklik bağlamında incelenirken Taraklı için Yavaş Şehir unvanının, Cumalıkızık için ise Dünya Miras Listesi'ne girmesi ve bu bölgede çekilen filmlerin bölgeye etkileri 
incelenmiştir. Bu kavramların turizmin sürdürülebilirliğine olan katkıları göz ardı edilemezken bazı olumsuzlukları da öne çıkarılarak irdelenmiştir.

\section{Taraklı: Yavaş Şehir Unvanı (Cittâslow)}

Cittâslow İtalyanca Cittâ (şehir) ve Slow (yavaş) kelimelerinin birleşmesiyle oluşturulmuştur. Türkçe'de genellikle sakin şehir olarak adlandırılan Cittâslow hareketi, doğal ve yerel değerlerin korunmasını ön planda tutarak kalkınma anlayışını savunmaktadır. Sakarya'nın Osmanlı mimarisi taşıyan tarihi bir kent dokusuna sahip Taraklı ilçesi de Türkiye'de Cittâslow üyesi olan 17 yerleşimden birisidir.

1986 yılında Roma'daki bir grup eylemci tarafından sosyalleşmeyi engellediği ve kültürel yozlaşmaya neden olarak gördükleri bir fast food zinciri restoranına karşı "Slow Food (yavaş yemek)" tepki hareketi ortaya çıkmıştır. Cittâslow (sakin şehir) Ağı ise, küreselleşmenin şehirlerin dokusunu, sakinlerini ve yaşam tarzını standartlaştırmasını ve yerel özelliklerini ortadan kaldırmasını engellemek için Slow Food hareketinden esinlenen bir kentler birliği organizasyonudur. Genel itibariyle Cittâslow, küreselleşmenin yarattığ homojen mekânlardan biri olmak istemeyen, yerel kimliğini ve özelliklerini koruyarak dünya sahnesinde yer almak isteyen kasabaların ve kentlerin katıldığı bir birliktir ("Cittaslow Türkiye", 2017).

Şehirlerin küreselleşmenin etkisiyle aynılaşıp hızlı yaşanılan, üretimden ziyade tüketime sahne olan ve bu nedenle kendi ihtiyaçlarına yetemeyen yaşam alanları haline dönüştüğü görülmektedir. Özellikle büyük şehirlerin koşturmalı yaşamının içinde insanlar tüm eylemlerini bir yere yetişme çabası içerinde hızlı yapmak durumunda kalır. Bu hızın içinde kentin eriyip gitmesi ve sürdürülemez hale gelmesi kaçınılmaz olmuştur. Cittâslow hareketi bu sorunları ortadan kaldırmak adına, insanların iletişimine olanak veren, üretimin sağlanabildiği ve şehrin kendine yetebildiği, yerelin özelliklerini koruyan, yenilenebilir enerji kaynaklarını kullanan ve gerektiğinde teknolojinin imkânlarını da yok saymayan bir anlayış ortaya koymaktadır.

Cittâslow organizasyonu, ulaşmak istediği hedefleri açısından ele alındığında; kentlerin yaşam kalitelerinin iyileştirilmesi ve 
geliştirilmesine dayalı yeni fikirlerin, farklı yollar ve yöntemler üzerinde düşünülerek oluşturulması ve oluşturulan yöntemlerin tüm ülkelerle paylaşılmasını hedeflemektedir. Bu bağlamda yerel toplulukların, kasabaların ve kentlerin günlük yaşantılarında yavaş yemek felsefesini uygulayabilecekleri ve bu felsefeyi büyütebilecekleri eko gastronomi kavramlarının geliştirilmesini ve organizasyonda yer alacak kentlerin bozulmamış manzara ve yapıları, sanat ve kültür faaliyetleri, yerel mutfak özellikleri, dini törenleri gibi varlıklarının özgünlügünü kaybetmeden korunması ve buralarda yaşayanların sakin hayat felsefesini benimsemesi şeklindeki kavramlara önem verildiği anlaşılmaktadır (Cittâslow International, 2016).

Taraklı Belediyesi bu hareket için başvurusunun ardından yapılan değerlendirme sonucu 50 puan barajını aşmış ve 2011 yılında Cittâslow üyesi olmaya hak kazanmıştır. Taraklı; Cittâslow üyeliğinden sonra, doğallık ve çevreyi koruma, tarihi siluete sahip çıkma, farkındalık oluşturma gibi çalışmalarına daha da önem vermeye başlamıştır. 2005 yılında yürürlüğe giren "Taşınmaz Kültür Varlıklarının Onarımına Yardım Sağlanmasına Dair Yönetmelik"ten faydalanılarak Taraklı'da restorasyon çalışmaları başlatılmış ve bu bağlamda 2006 yılında bir restorasyon atölyesi açılmıştır (Değirmenci ve Sarıbıyık, 2015).

Taraklı 'da simge haline gelmiş binalar restore edilmiş ve halen de edilmeye devam etmektedir (Şekil 2 ve 3). Bu yapıların kullanım amaçlarında da değişiklikler yapılarak sürdürülebilirliğe katkıda bulunulmuştur. Bir kısmı konaklama mekânı olarak kullanılıp turizmin sürdürülebilirliğine katkıda bulunurken bir kısmı kültür yapıları olarak yörenin özelliklerini tanıtıcı nitelikte sergileme imkânı sunmaktadır. Çarşıların restorasyonu ise geleneksel ürünlerin satılması kolaylaşmıştır. Belediyenin de desteği doğrultusunda geleneksel el sanatları teşvik edilmiştir.

Restorasyon atölyesi mimari değerlerin korunması açısından çok büyük bir adım olmuştur ve merkezde yer alan geleneksel esnafın desteklenmesi ile de kentsel yaşamın sürekliliği desteklenmiştir. Bunun yanında el yapımı ve etiketli ürünlerinin korunması, geleneksel iş tekniklerinin ve zanaatların değerinin arttırılması, kırsal bölgede yaşayanların hizmetlere erişimini arttırarak kırsal bölgelerin değerini arttırmak, yerel ve geleneksel kültürel etkinliklerin korunması ve değerlerinin 
arttırılması, tarımda GDO kullanımının yasaklanması, yerel ürünlerin sertifikalandırılması, kültür müzeleri kurulması gibi tarımsal, turistik, esnaf ve sanatkârlara dair politikalar da geliştirmeye çalışmıştır (Değirmenci ve Sarıbıyık, 2015). Kentin ziyaretçileri için görevlendirilen kişilere buna yönelik eğitimlerin sunulduğu ve yönlendirmeye dair levha yerleşimi ve tanıtım ofislerinin kurulmasına yönelik çalışmalar da yapılmıştır.

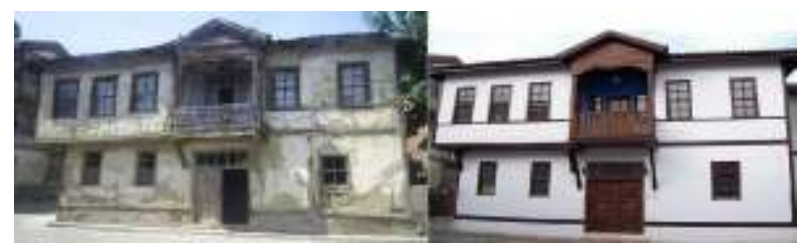

Şekil 2. Abdi İbrahim Konağı restorasyonu ("Abdi İbrahim Konağı", 2017)

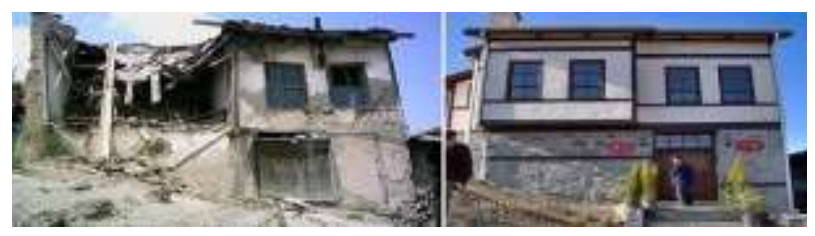

Şekil 3. Taraklı'da bir konut restorasyonu ("Taraklı restorasyon", 2017)

Tüm bu çalışmalar Taraklı' nın kimliğini kaybetmemesi, otantikliğini korumaya devam etmesi için önemli adımlardır. Yapıların aslına uygun şekilde restore edilmesi ve kullanıma açılması yok olmayı ve yeniden canlandırıldıktan sonra ise köhnemeyi önlemek için değerlidirler. Cittâslow'un tanımında bahsedilen doğallık, tarihi çevreyi korumanın yanı sıra yerel mutfak ögeleri, gelenek ve görenekler, yerel el sanatlarının teşviki gibi kavramlar da otantikliğin korunmasına katkıda bulunur.

Bunların haricinde ilçe merkezinin birkaç $\mathrm{km}$ dışında kurulan jeotermal tesislerin turizmin sürdürülebilirliğindeki etkisi tartışmalı bir konudur (Şekil 4). İlçeye ulaşımda motorsuz taşıtların özendirilmesi hem araç trafiğinin engellenmesi hem de ekolojik açıdan olumlu bulunmasının yanı sıra bu tesislerin kapasite olarak Taraklı'nın kaldırabileceğinin çok üstünde olması düşündürücü bir durumdur. 

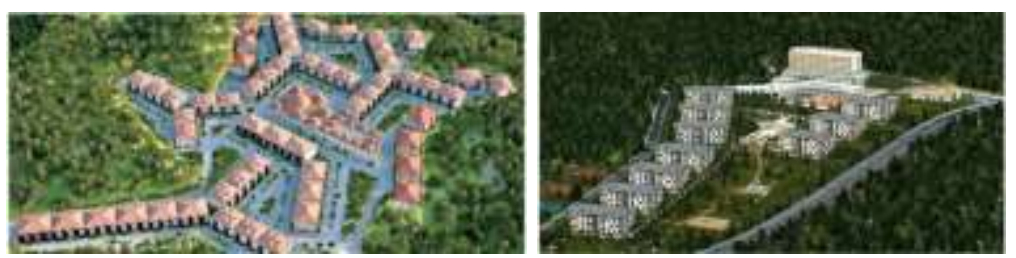

Şekil 4. İnşa edilen iki termal tesis ("Termal Tesis", 2017)

Tesislerin kapasitesine bakılacak olursa sadece bir tanesi için 1.200 daire ve 300 otel odasından oluştuğu bilgisi verilmiştir. Toplam kapasite düşünüldüğünde Taraklı için oldukça yüksek bir sayıdır. Tesis reklamlarında "Tarihin sadece binalarda yaşamadığı, eski gelenek ve göreneklere günlük hayatta çok sık bir şekilde rastlanabilen Taraklı, Cittâslow'un 180 üyesinden biridir. Sayısız film, reklam filmi ve belgesele ev sahipliği yapan Taraklı; tarihi konakları, göletleri, yaylaları ve sakin yaşamıyla huzurun ikinci adresi...("Taraklı Termal", 2017) " denilerek Taraklı ticari bir unsur olarak kullanılmıştır. Bu durumda bu tesislerin olumsuz etkileri ilçe merkezine yansımaması için ziyaretçi kontrolü politikaları geliştirilmelidir. Taraklı' nın Yavaş Şehir olarak kendi döngüsüne devam ederken bu oranda bir ziyaretçi akınına uğraması geleceği için tehdit oluşturmaktadır.

Taraklı Belediyesi, Cittâslow üyeliği dışında, Avrupalı Seçkin Destinasyonlar Projesi (EDEN) üyesidir. EDEN projesinin amaçları arasında; henüz keşfedilmemiş ve düşük turist yoğunluğuna sahip destinasyonların sürdürülebilir turizm ilkeleri doğrultusunda turistik cazibesinin arttırılması, turistik çekim unsurlarının geliştirilerek turist akışının yoğunlaştırılması ve bu sayede yerel ve bölgesel kalkınmanın hızlandırılması gösterilebilir. Taraklı, 2013 yılında erişilebilir turizm destinasyonu temasında, "2013 yılı Avrupalı Seçkin Turist Destinasyonu" ödülünü almıştır ("Eden Themes", 2017).

Ekim 2014'de Taraklı 'da, Taraklı İlçesi ve halkının sahip olduğu değerler ile ilçenin Cittâslow üyesi ve 2013 Eden Türkiye Birincisi olması göz önünde bulundurularak ilgili merkezi ve yerel idareler ile akademisyenlerin katılımıyla "Taraklı 'nın Dünü, Bugünü, Yarınları Çalıştayı" 
gerçekleştirilmiştir. Çalıştay sonuç raporuna göre alınan kararlar öne çıkan başlıklar şu şekilde özetlenebilir (Değirmenci ve Sarıbıyık, 2015) :

- Taraklı halkının kendine özgü sosyal yaşamını ve ilçenin tarihi dokusunu korumaya yönelik çalışmalar sürdürülmelidir. Bu amaçla Taraklı halkı bilinçlendirilmelidir.

- Tarihi Taraklı evlerinin hazırlatılacak bir plan çerçevesinde korumakullanma dengesinin sağlanarak yıllar içerisinde turizme kazandırılması sağlanmalıdır. Yapılacak restorasyon çalışmaları sonucunda mülk sahiplerince tarihi yapıların ikametgah olarak kullanımı teşvik edilmelidir.

- Henüz koruma altına alınmamış taşınmazlara yönelik Kültür ve Turizm Bakanlığı'nca tespit ve tescil işlemlerinin gerçekleştirilmesi sağlanmalıdır.

- Taşınmaz kültür varlıklarının onarımına yönelik, Kültür ve Turizm Bakanlığı'nca hibe şeklinde sağlanan yardımlar ile Toplu Konut İdaresi'nce verilen restorasyon kredileri hakkında taşınmaz sahiplerinin bilgilendirilmeli ve destek sağlanmalıdır.

- Restorasyon çalışmalarında ihtiyaç duyulan nitelikli işgücünün temin edilebilmesi için üniversite ile işbirliğine gidilmelidir.

- Halk eğitim merkezlerinde el sanatları konusunda eğitim verilmesinin devamlılığı sağlanmalıdır.

- İlçenin geçmişten gelen en önemli kültürel miraslarından biri olan yalaza kültürünün yaşatılması için belirli zamanlarda yalaza sohbetlerinin gerçekleştirilmesi ve tanitıc faaliyetlerin gerçekleştirilmesi gerekmektedir.

- Turistler için gezi rotaları belirlenmelidir. Oluşacak turist yoğunluğunun, Taraklı kültürü ve tarihi dokusu üzerindeki olumsuz etkilerinin azaltılmasına yönelik çalışmalar yapılmalıdır.

Çalıştayda pek çok konu üzerinde durulmuş ve hedefler kısaca özetlenmiştir. Tüm bunların gündeme gelmiş olması ve farkındalığın bu şekilde arttırılması ilçenin korunabilirliği ve böylece sürdürülebilirliği için önemli bir adım olmuştur.

\section{Cumalıkızık: UNESCO Dünya Mirası Listesi ve Film Turizmi}

2014 yllında UNESCO Dünya Miras Komitesi'nin 38. Dönem 
Toplantısı'nda "kültürel" kategoride Dünya Miras Listesi'ne alınan "Bursa ve Cumalıkızık: Osmanlı İmparatorluğu'nun Doğuşu” Dünya Miras Alanı, Cumalıkızık köyünün de dahil olduğu altı bileşenden oluşmaktadır. Özgün kırsal mimarisi ile alternatif tatil arzulayanlar için kırsal ve kültür turizmi anlamında, Bursa'nın ve Türkiye'nin önemli köylerinden biri haline gelmiştir. Cumalıkızık'ın Dünya Miras Listesi'ne alınmasıyla turistik önemi daha da artmıştır.(Köşklük Kaya, 2016). Cumalıkızık'ın UNESCO Dünya Miras Listesi'ne girmesinin getirdiği turistik çekim dışında dizi filmlere dekor oluşturması da turizmin gelişmesinde önemli bir etkendir (Şekil 5).

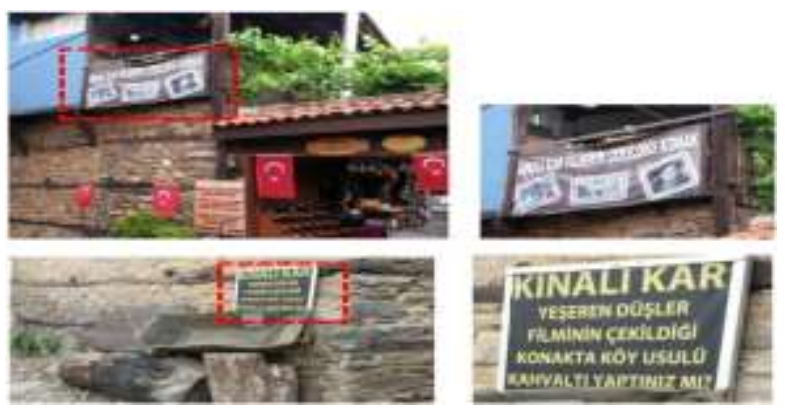

Şekil 5. "Kınalı Kar filminin çekildiği konak" ve "Kınalı Kar, Yeşeren Düşler filminin çekildiği konakta kahvaltı yaptınız mı?" yazıları ile filmin çekici unsur olarak kullanımı (Aktürk arşivi 2017)

Film turizmi, televizyon, video, DVD, VCD veya sinema ekranında destinasyon gösterimi sonucu ilgili destinasyon veya çekim yerine, film stüdyolarına, filmlerde kullanılan otellere ve evlere yönelik turist ziyaretleri olarak tanımlanır (Yılmaz ve Yolal, 2008). Yerel halkın da belirttiği gibi dizi film çekimlerinden sonra köye olan rağbet artmıştır ve günümüzde bu bir ticari unsur olarak kullanılmaktadır. "Filmin çekildiği ev“ olarak metalaştırılan birkaç konutun belli bölüleri bugün yeme içme mekânı olarak gelir elde etmektedir.

Dizinin çekildiği evler haricinde de köydeki pek çok konut gözleme ve kahvaltı evi olarak hizmet vermektedir. Bu üretim için sağlıklı mekânlar sağlanamamakla birlikte yön tabelaları ve konutların yeme mekânına dönüştürülmesi için yapılan eklemeler otantikliği bozmaktadır (Şekil 6)). 

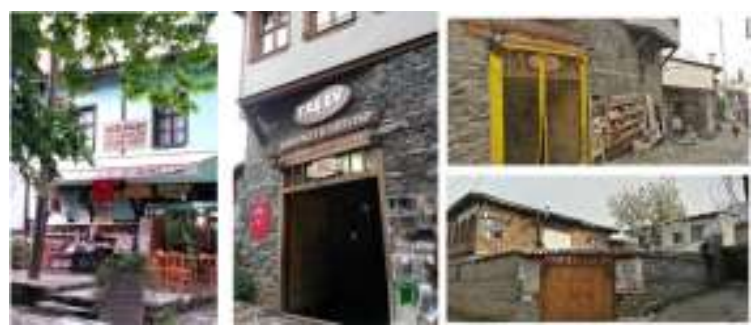

Şekil 6. Cumalıkızık'tayeme içme mekânına çevrilmiş konutlardan bazıları (Aktürk arşivi 2017)

Köyde yaygin olan bir diğer sektör ise meydanlarda ve sokaklarda tezgâh üzerlerinde ya da konutların cephelerine asılarak yapılan hediyelik eşya satıcılığıdır. Bu tezgâhlarda köye ait yerel ürünlerin yerine daha çok Çin malı eşyaların satılıyor olması büyük bir eksikliktir. Yöresel ürünlerin bu alanda daha az olması otantiklik bağlamında düşünüldüğünde hediyelik eşya satıcılığında kolay yönden ticari gelir tercih edilmiş ve üretim eksik kalmıştır.

Cumalıkızık'ta Kentsel Sit ile Kentsel Sit Etkilenme Alanı ve çevresi; alan kullanımları açısından incelendiğinde konut ve ticaret kullanımları, bahçetarla ve mezarlık alanları yer almaktadır. Doğusundan geçen derenin etrafı ağaçlık doku ile kaplıdır. Çekirdek alanın \%80'ini konut, $\% 10$ 'unu mezarlık, \%5'ini ticaret, \%3'ünü dini tesis, \%1'ini resmi kurum ve \%1'ini kültürel alanlar oluşturmaktadır. Tampon bölgenin ise $\% 50$ orman, \%40 tarım alanı, \%7 ticaret ve \%3 konuttan oluştuğu görülmektedir (Cumalıkızık Yönetim Planı, 2013). Yönetim planında kayıtlı olan ticari alanlar haricinde resmi haritalarda gözükmeyen fakat günümüzde farklı sektörlerde ticari faaliyetine devam eden pek çok konut yer almaktadır. Bu konutlar tespit edilip harita üzerine eklenmiş ve alana ait sektörel analiz yapılmıştır. Bu analizlerde ve köydeki pek çok yönlendirme tabelasında ticarileşmenin günümüzdeki boyutunu görebilmekteyiz (Şekil 7 ve 8). 

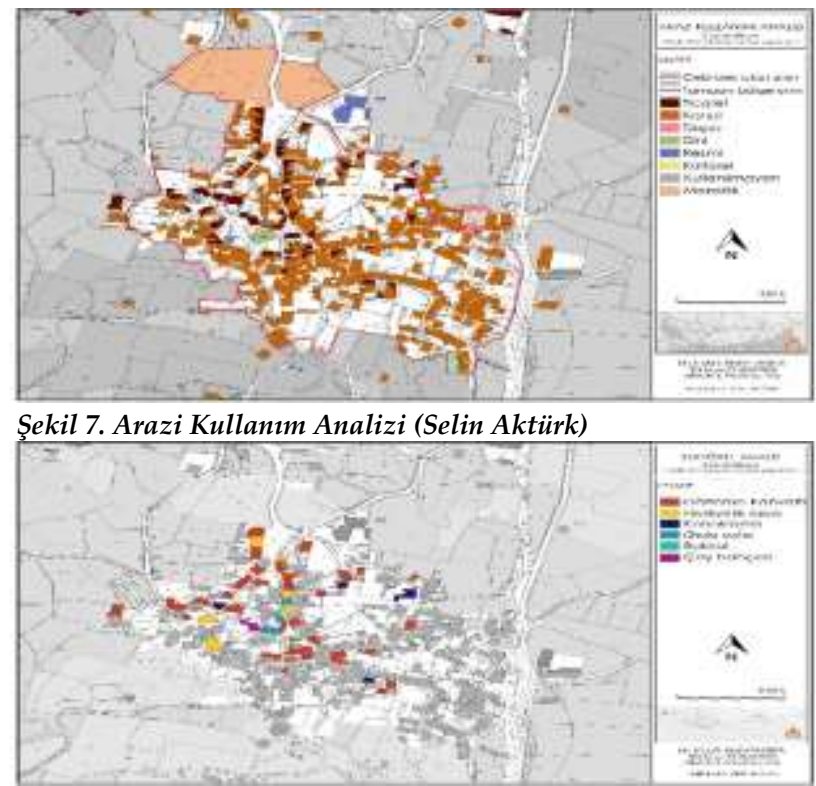

Şekil 8. Sektörel Analiz (Selin Aktürk)

Köylü ile yapılan görüşmelerde edinilen bilgiye göre tarım üretiminin getirisinin daha az olduğunu düşünen hemen herkes üretimi bırakıp turizmden gelir elde etmeye yönelmiştir. Günümüz durumuyla köy özellikle hafta sonları ziyaretçi akınına uğramakta ve köylü asıl işini bırakıp gelen turistlere hizmet vermektedir. Böyle günlerde, köy temelde sahip olduğu sakin yaşamdan tamamen uzaklaşıp yerini kalabalıklara birakmaktadır.

\section{Sonuç}

Turizmin yerel ekonomi üzerine etkilerinin planlanması sonucunda turizmi besleyen çevresel faktörlerin korunması, bu faktörlerin detaylı olarak bilinmesi ile ise turizm daha etkin hale getirilebilir. Bu nedenle ekolojik olarak hassas alanların turizme açılmadan önce yerel halkın sosyoekonomik durumu incelenmeli, turizm gelişimleri konusunda yaklaşımları ve çevrelerinde değerler ile ilgili görüşleri belirlenmeli ve elde edilen veriler ışığında turizm gelişmelerinin yerel halka sosyoekonomik açıdan katkıları açıklanmalıdır. Kısacası turizm konusunda yapılan 
çalışmaların başlangıcından itibaren yerel halk bu çalışmaların içerisine dahil edilmelidir (Mansuroğlu, 2006).

Taraklı için yapılan çalışmalara bakıldığında tarihi yapıların asıllarına uygun şekilde restore edilip kullanıma kazandırılması ilçenin tarihi dokusunun sürdürülebilirliğinde çok önemli bir etkendir. Bu çalışmalar için atölyelerin kurulması ve yöreyi tanıyan ustaların bu atölyelerde restorasyon işlerinde çalışmak üzere yetiştirilmesi önemli bulunmuştur. Cumalıkızık'ta restorasyon çalışmalarının bir kısmı tamamlanmış olmakla birlikte halen restore edilmeyi bekleyen pek çok konut bulunmaktadır.

Taraklı ilçesi' nin Cittâslow hareketine dahil olması ile birlikte yerleşim daha dikkat çekici olmaya başlamıştır. Bu sebeple ilçede bir iletişim firmasının reklamları çekilmiş ve Taraklı Belediyesi tarafından, güncel durumda bazı film çekimleri çalışmalarının yapılacağı bilgisi verilmiştir. Bölgenin tanınması açısından büyük bir rol üstlenen reklam ve filmler ilçenin doğal dengesini bozmayacak seviyeyi korudukları sürece değerlidir. Cumalıkızık Köyü'nün tanınmasında çok büyük rolü olan dizi çekimlerinin etkisi o bölgeye ticari bir unsur olarak yansımış ve neredeyse asıl değerlerin önüne geçmiştir. Günümüzde dizinin çekildiği evler olarak ünlenen birkaç konut kullandıkları büyük afişlerle bu durumu ilan etmekte ve bunu bir reklam unsuru haline getirmektedir. Hatta bu konutlar sahip oldukları ünü kullanarak bölgenin kültürüyle çok da alakası olmayan gözlemecilik sektörü ile zemin katı, bahçe ve teraslarını müşterilere açarak hizmet vermektedirler.

Taraklı' da sürdürülebilir kalkınmaya destek olacak bir diğer turizm hamlesi de jeotermal turizm potansiyelinin kullanılmasıdır. Kurulan tesislerin ilçe merkezinin dışında konumlandırılması ve aradaki mesafeyi motorsuz taşıtları teşvik ederek geçme düşüncesi hem otopark sıkıntısı ve trafik yoğunluğunu engellemek hem de doğayı korumak adına olumlu bir girişimdir. Fakat tesislerin kapasitesinin ilçenin kaldırabileceğinin çok üstünde olması aşikârdır. Bu durumda yerel yönetimler ziyaretçi kontrolü ile ilgili önlemler almalı ve böylece ilçenin kimliğini korumalıdır. Aksi takdirde Taraklı da Cumalıkızık'ta olduğu gibi hızla ticarileşecek ve günümüzde küçük bir çarşıda hizmet veren ticari alanlar yayılarak yapıların özgün işlevinin dışında kullanılmasına sebebiyet 
verecektir. Bu dönüşümler özgünlüğe, otantikliğe zarar vererek metalaşmanın önünü açacaktır.

Taraklı için değerlendirildiğinde Cittâslow kriterlerinde yöresel yiyecekler, geleneksel tatlar ve yöreye özgü el sanatları da desteklenmektedir. Uhut tatlısı, köpük helva gibi yöreye ait tatlar ön plana çıkarılıp etiketli ürün satışı yapılıyor olsa da el yapımı olarak satılan ürünlerin sahtecilikten uzak gerçekten yöreye özgü yapılarak satılması gerekmektedir. Cumalıkızık'ta günümüzde en yaygın ticaret unsuru kahvaltı ve gözlemeciliktir. Konutların alt katları gözleme imalatı ve yeme içme alanlarına dönüştürülmüştür. Gözlemenin yöresel bir değeri ve farkı olamamasına karşın kolay üretilen ve tüketilen bir yiyecek olması halkı bu üretime yöneltmiştir. Bu durumda yöreye ait unsurlar öne çıkarılarak halk bu üretime teşvik edilmelidir. Üretimin kontrolü sağlanmalıdır.

Taraklı İlçesi'nde yapılan altyapı çalışmaları ve çevre düzenlemeleri sürdürülebilirliğin çevresel boyutu için önemlidir. İçme suyu kalitesinin artırılması, elektrik kablolarındaki düzenlemeler, kanalizasyon sitemi çalışmaları bunlara örnektir.

Taraklı'nın ve Cumalıkızık'ın zaten kendisinde olan doğallık ve bunun getirdiği turizm potansiyeli reklamlarla, filmlerle, Cittâslow(Taraklı) hareketiyle ve UNESCO(Cumalıkızık) ile desteklenerek ön plana çıkarılmıştır. Önemli olan bu sürdürülebilirliği korumaktır. Henüz ticarileşmemiş, kendi halinde döngüsüne devam eden Taraklı'nın devamlılı̆̆1 ve sürdürülebilirliği bazı planlamalar göz önüne alınarak devam ettirilmelidir. Her iki alan için de yerel halk bilinçlendirilerek yerel değerlerin korunması amaçlanmalı ve sürdürülebilirliğe katkıda bulunulmalıdır. 
EXTENDED ABSTRACT

\title{
The Concept of Authenticity and Commodification in Sustainable Tourism and Examining of Cumalıkızık and Taraklı \\ *
}

\author{
Selin Aktürk - Selen Durak - Tülin Vural Arslan \\ Bursa Uludă̆ University
}

While the tourism sector includes many different factors, it can be mentioned that the developments or changes they have created in economic, ecological and social structure for each. Together with the changes in the understanding of tourism today, the expectations of tourists to gain different experiences have increased the demand for cultural tourism and rural tourism. As a result of this situation, some changes may occur in these societies and places that allow tourism.

The expectation of the tourist from rural or cultural tourism is to be closer to the natural, in other words, to experience the "authenticity". On the other hand, the effort to exhibit the authentic, which emerges from the desire of the local people to meet the economic expectations of tourism, can sometimes transform these places from natural to commercial products. When considered in terms of space, these "commodified" places with interventions and additions made on the basis of commercial expectation can turn into ornamental elements that cannot meet authentic expectations in time.

Definition of cultural tourism by World Tourism Organization; participation in education, art, festivals and events, visiting monuments and protected areas, examining nature or folklore and the movement of people with cultural motivations such as religious visits (Çetin, 2010). In the context of cultural tourism, a sub-heading is to evaluate the tourism potential of rural areas The pure life offered by rural life, various customs of the region, clothing styles, various meals made with natural products, building typologies varying according to regions attract the attention of tourists. The fact that the settlements are under protection or the title of Slow City increases this attraction even more. At this point, one of the most important concepts to be mentioned is "sustainability". 
World tourism organization defines sustainable tourism as increasing the quality of tourism capacity and products without negatively affecting the natural environment and human resources that feed the sector (Inam, 2009). While making this definition, the World Tourism Organization analyze the sustainability three basic topics; ecological, social, cultural and economic sustainability (Gürer, 2003).

"Authentic" word; it is defined as the original, which is real, based on truth or origin, and which possesses the features that have existed in the past. In the field of architectural conservation, authenticity is used as "true, sincere, original (Ulukan, 2014). The concept of authenticity in tourism is used and even sold to express local values. In this case, different expectations of local people and tourists are formed and the result is "commodification".

\section{Purpose, Scope and Method}

The main purpose of this study is to examine the effect of tourism sector, which is currently in search of alternative, in the places which are preferred in terms of local characteristics. It is aimed to provide a current contribution to the studies and to provide a framework for the balanced conservation of tourism regions that stand out with their authenticity.

Cumalıkızık Village of Bursa and Taraklı district of Sakarya were investigated as field study. After the literature review, the study was carried out with the interpretation of the information obtained from the analyzes in the fields. Meanwhile, photography and mapping methods have been used to document the current situation. In addition, interviews were conducted with the municipalities to which the settlements are connected.

\section{Findings and Conclusion}

While the areas were examined in the context of authenticity in sustainable tourism, the effects of slow city title for Tarakl1, Cumalıkızık's entry into the World Heritage List and the effects of the films taken in that regions were examined. 
Tarakli; after becoming a member of Cittâslow, he have been began to give more importance to his works such as protecting naturalness and environment, protecting historical silhouette and creating awareness. Restoration works were initiated in Taraklı in 2005 and a restoration workshop was opened in 2006 (Değirmenci and Sarıbıyık, 2015). Many buildings in Taraklı have been restored and some are still under restoration. The restoration of the bazaars have been made it easier to sell traditional products. Traditional crafts have been encouraged with the support of the municipality. In October 2014, a workshop was held in Taraklı with the participation of relevant central and local administrations and academicians. In this workshop, important decisions were made about the future of the settlement. In addition, policies on agricultural, touristic, craft and related trades workers such as the protection of handmade and labeled products, increasing the value of traditional business techniques and crafts, agriculture without GMO and certification of local products, increasing the access to services and the value of rural areas, preserving local and traditional cultural events and increasing the value have been developed (Değirmenci and Sarıbıyık, 2015). Work has also been carried out for the establishment of guidance plates and promotion offices for visitors.

Apart from these, the impact of geothermal facilities established a few $\mathrm{km}$ outside the district center on the sustainability of tourism is a controversial issue. Encouraging non-motor vehicles in transportation to the district was found to be positive in terms of the prevention of vehicle traffic and ecological aspects. But it is thought-provoking that these facilities are far above the capacity of Taraklı.

With the addition of Cumalıkızık to the World Heritage List, the importance of tourism in this village has increased (Köşklük Kaya, 2016). In addition to the touristic attraction of Cumalıkızık's entry into the UNESCO World Heritage List, the fact that it creates decor for series of films is also an important factor in the development of tourism. As the local people say, after the filming of the series, the demand for the village has increased and nowadays this situation is used as a commercial 
element. Many houses in the village serve as pancake and breakfast houses. In this case, in addition to the lack of healthy spaces for production, the signposts and additions for the conversion of houses into eating spaces spoil the authenticity. Another sector which is common in the village is selling souvenirs in the squares and streets by hanging them on the counter or on the façades of the houses. It is a great deficiency that these products are sold mostly from Chinese goods instead of local products. According to the information obtained from the interviews with the villagers, almost everyone who thinks that the income of agriculture is less has turned to generating income from tourism by abandoning production.

The naturalness that Taraklı and Cumalıkızık already possessed and the tourism potential it brings, has been brought to the forefront with ads, films, Slow City (Taraklı) movement and UNESCO (Cumalıkızık). It is important to maintain sustainability. Henüz ticarileşmemiş, kendi halinde döngüsüne devam eden Taraklı'nın devamlılığı ve sürdürülebilirliği bazı planlamalar ile devam ettirilmelidir. For both areas, local people should be made aware of the need to protect local values and contribute to sustainability.

\section{Kaynakça / References}

Cumalıkızık Yönetim Planı. (2013). Bursa: Bursa Büyükşehir Belediyesi.

Abdi ibrahim Konağı. (2017, Mayıs 28). Restorasyon Forum: http://www.restorasyonforum.com/index.php?topic=1523.0 adresinden alınmıştır.

Cittaslow Türkiye. (2017, Mayıs 28). Cittaslow Türkiye: http://cittaslowturkiye.org adresinden alınmıştır.

Eden Themes. (2017, Mayıs 30). Europa Tourism: http:/e c.europa.eu/enterprise/sectors/ tourism/eden/ index_tr.htm adresinden alınmıştır.

Taraklı. (2017, Nisan 1). Wikipedia: https://tr.wikipedia.org/ adresinden alınmıştır.

Taraklı restorasyon. (2017, Mayıs 28). Restorasyon Forum: http://www.restorasyonforum.com/index.php?topic=1523.0 adresinden alınmıştır.

Taraklı Termal. (2017, Mayıs 30). Taraklı Termal: http://www.taraklitermal.com.tr adresinden alınmıştır. 
Termal Tesis. (2017, Mayıs 28). Geyve Medya: http://www .geyvemedya.com adresinden alınmıştır.

Çakılcıŏlu, M. (1996). Sürdürülebilir turizme yönelik bir yöntem önerisi, Doğu Karadeniz/Trabzon ili özelinde bir irdeleme. İstanbul: Doktora tezi, Mimar Sinan Güzel sanatlar Üniveristesi Fen Bilimleri Enstitüsü.

Çetin, T. (2010). Cumalıkızık köyünde kültürel miras ve turizm algısı. Milli Folklör Dergisi, 22(87), 181-190.

Değirmenci, İ., ve Sarıbıyık, M. (2015). Tarihi mekanlarda sürdürülebilirlik bağlaminda Cittaslow hareketi : Taraklı örneği. 2.Uluslararası Sürdürülebilir Yapılar Sempozyumu (s. 612-620). Ankara: Gazi Üniversitesi.

Erdemli, E. (2012). Çalışma hayatı ve ev işlerini birlikte yürüten kırsal kadının yaşam modeli: Cumalıkızık Köyü örneği . İstanbul: Yüksek Lisans Tezi, İstanbul Üniversitesi Sosyal Bilimler Enstitüsü.

Garda, B., ve Temizel, M. (2016). Sürdürülebilir turim çeşitleri. Selçuk Üniversitesi Sosyal ve Teknik Araştırmalar Dergisi, 12, 83-103.

Greenwood, D. J. (1977). Culture by the Pound: An Anthropological Perspective on Tourismas Cultural Commoditization in Smith, V. L. (ed.) Hosts and Guests, Philadelphia: University of Pennsylvania Press, pp. $129-139$

Gürer, N. (2003). Kırsal geleneksel konut dokusunun turizm bağlaminda değerlendirilmesi, Cumalıkızık örneği . Ankara: Yüksek lisans tezi, Gazi Üniversitesi Fen Bilimleri Enstitüsü.

İnam, E. A. (2009). Sürdürülebilir turizm bağlamında yöre imgesi: AntalyaBelek turizm merkezi örneği. İstanbul: Doktora tezi, Yıldız Teknik Üniversitesi Fen Bilimleri Enstitüsü.

Kan, H. (2009). Taraklı yerleşimindeki tarihi dokunun sürdürülebilirliği bağlamında kentsel koruma ve geliştirme stratejileri. Bartın: Yüksek Lisans Tezi, Bartın Üniversitesi Fen Bilimleri Enstitüsü.

Kaya, N. (2016). Kırsal mimarlık mirasının korunmasında turizmin rolü: $\mathrm{Cu}-$ malıkızık örneği. Ege Mimarlık Dergisi, ocak, 28-31.

Kaygalak, S., Usta, Ö., ve Günlü, E. (2013). Mardin'de turizm gelişimi ile otantik olgusu arasındaki ilişkinin sosyolojik açıdan değerlendirilmesi. Anatolia Turizm Araştırmaları Dergisi, 4(2), 237-249.

MacCannell, D. (1999). The tourist a new theory of the leisure class. California: University of California Press. 
Mansuroğlu, S. (2006). Turizm gelişmelerine yerel halkın yaklaşımlarının belirlenmesi: Akseki/Antalya örneği. Akdeniz Üniversitesi Ziraat Fakiltesi Dergisi, 9(1), 35-46.

Özünel, E. Ö. (2011). Kültür turizminde yöresel ve otantik olanı sorgulamak ve tüketilmiş mekanları yeniden üretmek üzerine. Literature and History or Turkic Volume, 6(4), 255-262.

Sedmak, G., ve Mihalic, T. (2008). Authenticity in mature seaside resorts. Annals of Tourism Research, 35(4), 1007-1031.

Taylor, J. P. (2001). Authenticity and sincerity in tourism. Annals of Tourism Research, 28(1), 7-26.

Ulukan, M. (2014). Mimari korumada otantiklik üzerine yöntem araştırması ve İstanbul tekkelerinde uygulama örnekleri. İstanbul: Doktora tezi, İstanbul Teknik Üniversitesi Fen Bilimleri Enstitüsü.

Wang, S., Fu, Y., Cecil, A., ve Avgoustis, S. (2006). Residents' perceptions of cultural tourism and guality of life. Tourizm Today, 6, 47-61.

WTO (The World Tourism Organization) Yayını, (2001). Tourism in the Year

WTO (The World Tourism Organization) Yayını, (2004). Indicators of Sustainable Development for Tourism Destinations

Yılmaz, H. S. (1999). Bursa, Cumalıkızık Köyü'nün tarihi değerlerinin korunması üzerine bir inceleme . İstanbul: Yüksek Lisas Tezi, İstanbul Teknik Üniversitesi Fen Bilimleri Enstitüsü.

Yılmaz, H., ve Yolal, M. (2008). Film turizmi: Destinasyonların pazarlanmasında filmlerin rolü. Anadolu Üniversitesi Sosyal Bilimler Dergisi, 8(1), 175-192.

\section{Kaynakça Bilgisi / Citation Information}

Aktürk, S., Durak, S. ve Vural-Arslan, T. (2019). Otantiklik ve metalaşma kavramlarının turizmin sürdürülebilirliği çerçevesinde Taraklı ve Cumalıkızık bölgeleri üzerinden okunması. OPUS-Uluslararası Toplum Araştırmaları Dergisi, 13(19), 2200-2225. DOI: 10.26466/opus.569837 